\title{
The Armey Curve Hypothesis-based Environmental Kuznets Curve (EKC) Hypothesis Testing Across the US States with Government Spending
}

Cem Işık ( $\nabla$ cemisik@anadolu.edu.tr)

Anadolu Universitesi https://orcid.org/0000-0001-5125-7648

\section{Serdar Ongan}

St Mary's College of Maryland

Umit Bulut

Kirsehir Ahi Evran Universitesi

\section{Sahir Karakaya}

Galatasaray Universitesi

Muhammad Irfan

Beijing Institute of Technology

\section{Rafael Alvarado}

Universidad Nacional de Loja

\section{Munir Ahmad}

Zhejiang University

Abdul Rehman

Henan Agricultural University

\section{Research Article}

Keywords: The Armey curve hypothesis, the EKC hypothesis, New version of the EKC hypothesis testing.

Posted Date: June 30th, 2021

DOl: https://doi.org/10.21203/rs.3.rs-581489/v1

License: (1) (1) This work is licensed under a Creative Commons Attribution 4.0 International License.

Read Full License 
The Armey Curve Hypothesis-based Environmental Kuznets Curve (EKC)

2 Hypothesis Testing Across the US States with Government Spending

3

4

5

6

7
Cem Işık (Corresponding Author)

Faculty of Tourism, Anadolu University, Eskişehir, Turkey; cemisik@anadolu.edu.tr

Serdar Ongan

Department of Economics, St. Mary's College of Maryland, St. Mary’s City, MD, 20686, USA; songan@smcm.edu

\section{Umit Bulut}

Faculty of Economics and Administrative Sciences, Kirsehir Ahi Evran University, Kirsehir, Turkey, ubulut@ahievran.edu.tr

\author{
Sahir Karakaya \\ Department of Economics, Galatasaray University, İstanbul, Turkey; \\ skarakaya@gsu.edu.tr

\section{Muhammad Irfan} \\ School of Management and Economics, Beijing Institute of Technology, Beijing 100081, \\ China; irfan@ncepu.edu.cn

\section{Rafael Alvarado} \\ Carrera de Economía, Universidad Nacional de Loja, Loja 110150, Ecuador \\ jose.r.alvarado@unl.edu.ec \\ Munir Ahmad \\ School of Economics, Zhejiang University, Hangzhou 310058, China; \\ munirahmad@zju.edu.cn \\ Abdul Rehman \\ College of Economics and Management, Henan Agricultural University Zhengzhou \\ 450002, China, abdrehman@ henau.edu.cn
}


55

Abstract: This study re-tests the EKC hypothesis for US states with a new methodology that differs from all previous empirical studies using traditional EKC models. To this aim, this methodology, for the first time, unifies two seemingly different but strongly interrelated hypotheses (models), namely the Armey curve (AC) and traditional EKC models, into one single composite model. The rationale for creating this composite model is twofold. First, the functional propositions of these two hypotheses are depicted with inverted U-shaped curves. Second, they also have economically interrelated-causal relationships. This means that rising government spending (through the AC hypothesis) increases real GDP per capita (RGDPPC) and, consequently, increases in RGDPPC (through the EKC hypothesis) increase $\mathrm{CO}_{2}$ emissions. The composite model created may also allow US state policymakers to determine a single maximum spending level that will maximize or minimize $\mathrm{CO}_{2}$ emissions. Empirical findings indicate that the composite model is capable of testing the EKC hypothesis for 7 US states. Additionally, for 7 US states, maximum spending level was calculated to be around $15 \%$ of their RGDPPCs. Hence, with this calculated spending level, policymakers of these states may be able to determine-adjust their golden spending levels so as not to cause environmental degradation and declines in GDP.

Keywords: The Armey curve hypothesis, the EKC hypothesis, New version of the EKC hypothesis testing.

Jel Classification: E62, Q50. 


\section{Introduction}

60 The roles of the governments in economic growth have been discussed for a long time. In

61 the theoretical discussion, the neoclassical growth model, developed by Solow (1956),

62 postulates that fiscal policies through taxation and government spending can affect the

63 economic growth up to only a steady-state rate of growth, which is determined by the

64 exogenous rate of technological progress. On the other hand, the endogenous growth model, 65 pioneered by Romer (1986), Lucas (1988), and Barro (1990), postulates that a government

66 can affect the economic growth since transition and steady-state growth rates and

67 government is considered endogenous. This means that governments play a serious role in

68 the economy. From a closer perspective, this discussion implicitly arises from a basic

69 question about how much should a government be involved in the economy? According to

70 Armey (1995), rises in government spending trigger economic growth only up to a threshold

71 (turning) point. Further rises in spending lead to falls in growth and the initially linear

72 relationship between growth and spending becomes nonlinear just after this threshold point

73 (optimal government spending level). This nonlinear relationship postulated draws a

74 parabolic inverted U-shaped curve, the so-called Armey curve shown in Figure 1. The

75 rationale of this expectation is that real GDP per capita will initially increase by increasing

76 productive government spending and eventually decrease after a threshold (turning) point

77 due to different dynamics, such as the crowding-out effect, taxation, the law of diminishing

78 returns, and bureaucratic costs (Bastiat 1983; Barro, 1990; Scully, 1996; Karras, 1997; Chao

79 and Grubel, 1998; Sarte, 2001; Colombier, 2009).

80 
84 The pattern of this curve gives government policymakers the maximum level of spending

85 which could maximize their real GDP per capita. On the basis of causal interconnectivity

86 among the macroeconomics variables in the economy, the Armey curve resembles another

87 inverted U-shape curve, the so-called Environmental Kuznets Curve (EKC), developed

88 by Grossman and Krueger (1991), shown in Figure 2. According to the EKC hypothesis,

89 in the first stages of economic growth, rises in the real GDP per capita initially lead to

90 increases in environmental degradation ( $\mathrm{CO}_{2}$ emissions) but further rises eventually lead

91 to decreases in emissions after a certain turning point. In a way similar to the Armey curve

92 hypothesis, this certain point gives government policymakers the maximum level of real

93 GDP per capita, which will trigger declines in $\mathrm{CO}_{2}$ emissions.

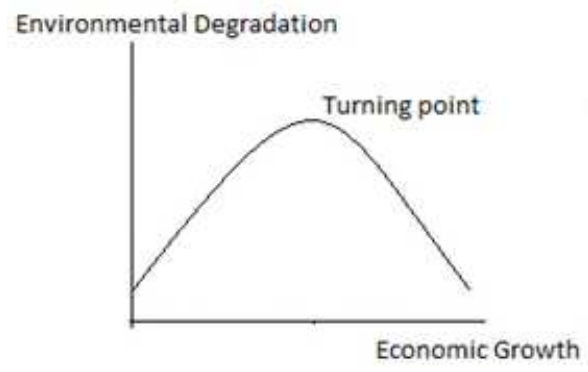


98 When these two hypotheses (curves) are closely examined, a sequentially causal 99 relationship can be clearly seen from the Armey curve hypothesis to the EKC hypothesis. 100 This means that rises in government spending lead to increases in real GDP per capita in 101 the Armey curve model and, thereby, rises in real GDP per capita lead to increases in $\mathrm{CO}_{2}$ 102 emissions in the EKC model. Moreover, this variable-level causal relationship between 103 the two models was constructed on the same inverted U-shaped mathematical proposition. 104 Therefore, we believe that these two hypotheses can be jointly examined, both 105 theoretically and mathematically. This means that such similarity may enable us to test 106 the EKC hypothesis through the Armey curve hypothesis (model). Therefore, it can be 107 interpreted that the EKC hypothesis can be potentially tested by a kind of transmission 108 mechanism of the Armey curve model. In this context, a single composite model derived 109 from these two hypotheses (models) can be set up. To the best of our knowledge, this new 110 methodological approach proposed using a single composite model will be the only 111 attempt used in testing the EKC hypothesis in relevant literature. This alternative approach 112 of testing the EKC hypothesis and transmission mechanism can be shown in the following 113 Figure 3: 


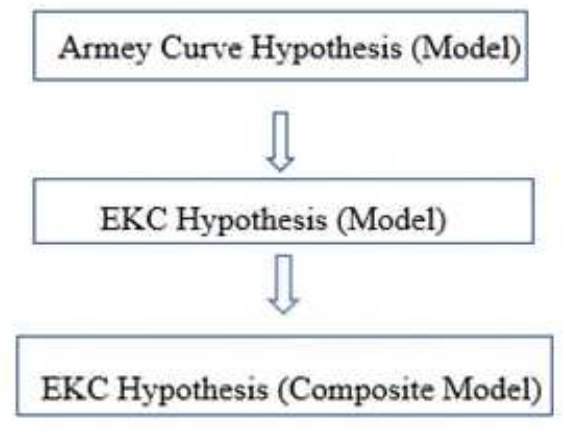

115

116

117

118

119

120

121

122

123

124

125

126

127

128

129

130

131

132
Figure 3: EKC Hypothesis Testing Through

the Armey Curve Hypothesis

Therefore, we will try to test the EKC hypothesis in this methodological context for 50 US states from 1990-2017 based on the latest available year data. The rationale of a state-level empirical study is that US states have different levels of real GDP per capita, spending, $\mathrm{CO}_{2}$ emissions, and energy policies. These differences make the USA a unique sample country. Another advantage of sampling US states is that this country provides a wide range of data at the state level for more detailed empirical results. The necessary conditions for testing the EKC hypothesis through the Armey curve model are as follows: first, the Armey curve must be validated for a sample US state. Second, the composite model must be significant for the same US state. This means that the curve shape of the Armey model must be inverted U-shaped. However, significant composite model can be either U-shaped or inverted Ushaped. If the composite model's curve is also inverted U-shaped, this will imply that the EKC hypothesis is validated through the Armey curve hypothesis (Case 1 in Figure 4). Otherwise, significant but U-shaped curve will not validate this hypothesis through the Armey curve model (Case 2 in Figure 5). In the following Figures 4 and 5, we graphically 
133 depict these two potential curve cases of the composite EKC model with a validated Armey 134 curve hypothesis.

138

139

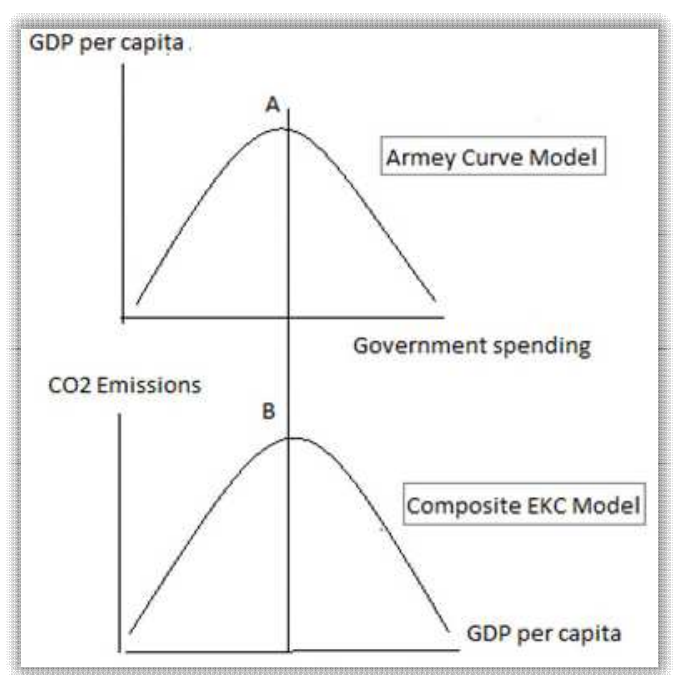

Figure 4: Case 1

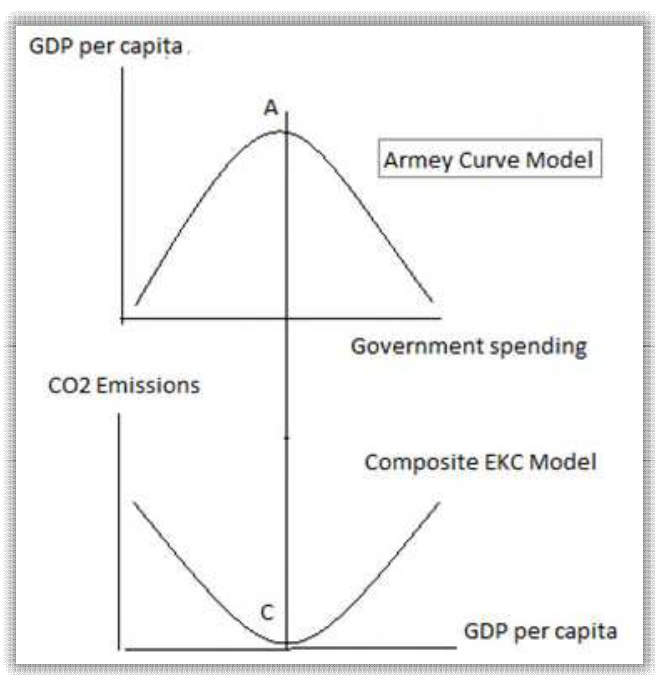

Figure 5: Case 2

141 This proposed alternative EKC hypothesis testing method may provide an important 142 advantage to US state policymakers in these two different cases. Case 1 may enable them 143 to determine a maximum (optimal) spending level (through a maximum real GDP per capita 144 level: point A) that maximizes $\mathrm{CO}_{2}$ emission (point B). Hence, the policymakers may know 145 that additional spending after point $\mathrm{A}$ will decrease real GDP per capita and $\mathrm{CO}_{2}$ emission, 146 implying a dilemma between cleaner environment or lower real GDP per capita. From this 147 point of view, they may determine a golden (optimal) ratio reckoning with the potential 148 changes in real GDP per capita and $\mathrm{CO}_{2}$ emission as a whole. Case 2 may enable them to 149 determine a maximum (optimal) public spending level (through a maximum real GDP per 
150 capita level: point $\mathrm{A}$ ) that minimizes $\mathrm{CO}_{2}$ emission (point $\mathrm{C}$ ). Hence, policymakers may

151 know that additional spending, after point A, will decrease real GDP per capita and increase

$152 \mathrm{CO}_{2}$ emission (point $\mathrm{C}$ ), implying no more government spending is needed after point $\mathrm{A}$.

153 To some degree, this proposed methodological approach also enables US state policymakers

154 to find out whether their economic growth and energy policies are compatible with each

155 other and sustainable or how these two policies interact with each other. In this

156 interpretation, while we regard economic growth policy with the Armey curve hypothesis

157 (based on government spending), we regard energy policy with the EKC hypothesis (based

158 on increases in real GDP per capita). Therefore, policymakers in cross-border states can

159 develop some common economic and energy policies to ensure more sustainable

160 environment. The following sections of the study are: Section 2 provides a summary

161 literature review. Section 3 explains the empirical model and estimation methodology.

162 Sections 4 and 5 provide the empirical findings and the conclusion with policy implications, 163 respectively.

165 2. Literature Review

166 In this section, we provide the empirical studies which have tested the Armey and the EKC

167 curves hypotheses individually for the US or in a group of countries such as those of the 168 OECD and the G-7 group. Table 1 reports these studies with the empirical methodologies 169 used and their findings.

170

171 Table 1: Empirical Studies in the Armey Curve and EKC Hypotheses

Armey Curve Hypothesis 


\begin{tabular}{|c|c|c|}
\hline & Methodology & Findings \\
\hline Vedder and Gallaway (1998) & OLS Regression & Valid \\
\hline Knoop (1999) & OLS Time Series & Not Valid \\
\hline $\begin{array}{l}\text { Dar and Amir Khalkhali } \\
\text { (2002) }\end{array}$ & $\begin{array}{l}\text { random coefficients } \\
\text { model }\end{array}$ & Not Valid \\
\hline Roy (2009) & Simultaneous Equations & Not Valid \\
\hline Connolly and Li (2016) & GMM & Not Valid \\
\hline $\begin{array}{l}\text { Bozma, Başar, and Eren } \\
\text { (2019) }\end{array}$ & ARDL Cointegration & Valid \\
\hline Rajput and Tariq (2019) & GMM & Not Valid \\
\hline \multicolumn{3}{|c|}{ EKC Hypothesis } \\
\hline Dogan and Turkekul (2016) & Bounds Testing & Not Valid \\
\hline Dogan and Ozturk (2017) & $\begin{array}{l}\text { Bounds Testing and } \\
\text { Gregory-Hansen } \\
\text { Cointegration }\end{array}$ & Not Valid \\
\hline Shahbaz et al. (2017) & $\begin{array}{l}\text { Bounds Testing with } \\
\text { Structural Break }\end{array}$ & Not Valid \\
\hline Apergis et al. (2017) & Panel Estimators & $\begin{array}{l}\text { Valid in } 10 \text { out of } \\
48 \text { US States }\end{array}$ \\
\hline Aslan et al. (2018) & $\begin{array}{l}\text { Bootstrap window } \\
\text { estimation }\end{array}$ & Valid \\
\hline Is1k et al. (2019) & CCE & $\begin{array}{l}\text { Valid in } 5 \text { out of } 10 \\
\text { US States }\end{array}$ \\
\hline Ongan et al. (2021) & Decomposition & $\begin{array}{l}\text { Valid by } \\
\text { Decomposed model }\end{array}$ \\
\hline
\end{tabular}


175

176

177

178

179

180

181

182

183

184

185

186

187

188

189

190

191

192

\begin{tabular}{|l|l|l|}
\hline Khan and Hou (2021) & Cointegration Analysis & Valid
\end{tabular}

Note: ARDL: Autoregressive distributed lag; OLS: Ordinary Least Square; GMM: Generalized Method of Moments; CCE: Common Correlated Effects.

Empirical studies in Table 1 clearly reveal mixed results about the validity of the Armey curve and EKC hypotheses. This may stem from the different methodologies applied, time frames examined, and different variables used in the models.

\section{Empirical Model and Estimation Methodology}

The empirical model of this study was theoretically constructed based on Figure 3 in the introduction section. Hence, to create our composite EKC model, we, first, write the following Armey curve model in the natural logarithmic form for the 50 US states:

$$
\ln D I_{i t}=\alpha+\beta \ln S_{i t}+\gamma \ln S_{i t}^{2}+\zeta \ln E C_{i t}+\varepsilon_{i t}
$$

where $D I$ is state-level per capita real disposable personal income as the proxy of real GDP per capita. $S$ and $S^{2}$ are state government spending and squared value of state government spending, respectively; $E C$ is total energy consumption. According to the Armey curve hypothesis, the signs for $\beta$ and $\gamma$ are expected to be significantly positive and negative, respectively. If these two coefficients are characterized by these signs $(\beta>0 ; \gamma<0)$, it is implied that the Armey curve hypothesis is valid for a US state. This means that rises in 
193 spending will initially lead to increases in real GDP per capita up to a threshold point

194 (optimal state government spending level) and eventually lead to decreases in it. The dataset 195 and definitions of the variables are provided before the references section.

196 Following the Armey curve model in Eqn. 1, we present the EKC hypothesis model in the 197 following form:

198

$$
\ln C O 2_{i t}=a+b \ln D I_{i t}+c \ln D I_{i t}^{2}+z \ln E C_{i t}+\varepsilon_{i t}
$$

200

201 where $\mathrm{CO}_{2}$ is state-level carbon emissions, $D I$ and $D I^{2}$ are state-level per capita real 202 disposable personal income and squared value of per capita real disposable personal income, 203 respectively. EC is total energy consumption. According to the EKC hypothesis, the signs 204 for $b$ and $c$ are expected to be significantly positive and negative, respectively. If these two 205 coefficients are characterized by these signs $(b>0 ; c<0)$, it is implied that the EKC 206 hypothesis is valid for a US state. This means that rises in income will initially lead to an 207 increase in $\mathrm{CO}_{2}$ emissions and eventually lead to a decrease in it after a maximum point of 208 income.

209 From the models in Eqns. 1 and 2, we create-obtain the following composite model without $210 E C$ in Eqn. 3. To show the methodological approach of this study clearly, we have designed 211 the model in the following form without $E C$ :

$$
\operatorname{lnCO2} 2_{i t}=a+b(\underbrace{\alpha+\beta \ln S_{i t}+\gamma \ln S_{i t}^{2}}_{D I})+c(\underbrace{\alpha+\beta \ln S_{i t}+\gamma \ln S_{i t}^{2}}_{D I^{2}})^{2} \ldots \ldots \ldots \ldots \varepsilon_{i t}
$$


215 Hence, with this model formula, we can test the EKC hypothesis through the Armey curve 216 model mathematically since the independent variables of the EKC model (DI and $\left.D I^{2}\right)$ will 217 be represented by the independent variables of the Armey curve model in parentheses ( $S$ 218 and $S^{2}$ ). The EKC hypothesis is validated if the signs for $b$ and $c$ (corresponding to DI and $219 D I^{2}$ ) are positive and negative, respectively.

220 To determine the maximum (optimal) government spending level that will maximize (Case 2211 in Figure 4) or minimize (Case 2 in Figure 5) $\mathrm{CO}_{2}$ emissions, we have created and used 222 the following steps and formulae:

223

224 From the first order optimization condition $d \ln D I / d \ln S$ applied to Eqn. 1, we obtain the 225 state government spending level as,

$226 \quad \ln S=-\frac{\beta}{2 \gamma}$

227 The sufficient condition for maximization is $d^{2} \ln D I / d \ln S^{2}=2 \gamma<0$, so $\gamma$ is expected 228 to be $<0$. For data consisting of $S_{i}>1, \ln S$ is positive, so $\beta$ is expected to be $>0$. Later, 229 we obtain the optimal level for the composite model in Eqn. (3), from the first-order 230 condition $\mathrm{dCO}_{2} / \mathrm{dS}$ :

$231 \quad \ln S_{1}=-\frac{\beta}{2 \gamma}$

232

$$
\ln S_{2,3}=\frac{-\beta \pm \sqrt{\beta^{2}-2\left(\frac{b}{c}\right) \gamma-4 \alpha \gamma}}{2 \gamma}
$$


233 The value of $\ln S=-\frac{\beta}{2 \gamma}$ in Eqn.4 will be the optimal $\mathrm{CO}_{2}$ emissions level for Eqn. (3).

234 When we insert the value of $\ln S=-\frac{\beta}{2 \gamma}$ into $d^{2} \mathrm{CO} 2 / d \ln S^{2}=2 \mathrm{~b} \gamma+2 \mathrm{c}(\beta+2 \gamma \ln S)^{2}+$ $2354 c \gamma\left(\alpha+\beta \ln S+\gamma \ln S^{2}\right)$, we obtain the following formula:

$237 \frac{d^{2} \operatorname{CO} 2}{d \ln S^{2}}\left(\ln S_{1}\right)=-c \beta^{2}+2 \mathrm{~b} \gamma+4 c \alpha \gamma$

238

239 if $\gamma<0$ and $-c \beta^{2}+2 \mathrm{~b} \gamma+4 c \alpha \gamma>0$, it means that the Armey curve has an inverted U-

240 shape and the composite EKC is U-shaped. If $\gamma<0$ and $-c \beta^{2}+2 \mathrm{~b} \gamma+4 c \alpha \gamma<0$, it

241 means that the Armey curve and the composite EKC are both inverted U-shaped. Finally,

242 to estimate the coefficients of the model in Eqn. 3, we have followed several methodological

243 steps in the following sub-titles.

244

245

\subsection{Cross Sectional Dependence and Heterogeneity Tests}

246 The empirical analysis begins with testing cross-sectional dependence and slope 247 heterogeneity in the panel data set. The paper performs the Lagrange Multiplier (LM), CD, $248 \mathrm{CD}_{\mathrm{LM}}$, and $\mathrm{LM}_{\mathrm{adj}}$ tests to examine whether cross-sectional dependence exists. While the LM 249 test was produced by Breusch and Pagan (1980), CD and CD $\mathrm{LM}_{\mathrm{L}}$ tests were suggested by 250 Pesaran (2004). In addition, LMadj test was propounded by Pesaran et al. (2008). The paper 251 also employs $\widetilde{\Delta}$ and $\widetilde{\Delta}_{\text {adj }}$ tests to investigate the possible presence of slope heterogeneity. 252 Both tests were developed by Pesaran and Yamagata (2008). While cross-sectional 
253 dependence tests search for the null hypothesis of no cross-sectional dependence,

254 heterogeneity tests examine the null hypothesis of slope homogeneity.

255

256 3.2. Pesaran (2007) Panel Unit Root Test

257 This paper carries out the augmented Dickey-Fuller (henceforth, CADF) panel unit root test

258 of Pesaran (2007) to examine whether there is a unit root in the variables under 259 consideration. This panel unit root test considers the null hypothesis of a unit root and can

260 reveal biased and efficient output in the existence of slope heterogeneity and cross-sectional 261 dependence in the panel data model.

262

263

264 3.3. Westerlund (2007) Panel Cointegration Test

265 To test cointegration in the presence of cross-sectional dependence, Westerlund (2007)

266 produces panel cointegration tests based on the error correction model. Among these tests, $267 \quad \mathrm{P}_{\mathrm{t}}$ and $\mathrm{P}_{\mathrm{a}}$ statistics are defined as panel statistics and they depend on pooling information on 268 error correction across cross sections in the panel. Besides, $G_{t}$ and $G_{a}$ are called group mean 269 statistics and they do not use the information utilized by panel statistics. The null hypothesis 270 of no cointegration is tested for all tests. Westerlund (2007) uses the panel regression model 271 defined as follows:

272

273

$$
\Delta \mathrm{Y}_{\mathrm{it}}=\delta_{\mathrm{i}}^{\prime} \mathrm{d}_{\mathrm{t}}+\lambda_{\mathrm{i}}^{\prime} \Delta \mathrm{X}_{\mathrm{it}}+\gamma_{\mathrm{i}} \mathrm{Y}_{\mathrm{it}-1}+\varphi_{\mathrm{i}} \mathrm{X}_{\mathrm{it}-1}+\varepsilon_{\mathrm{it}}
$$


274 where $d_{t}$ indicates deterministic components, $\lambda_{\mathrm{i}}$ shows long-run parameters, and $\alpha_{\mathrm{ij}}$ and $\gamma_{\mathrm{ij}}$

275 stand for short-run parameters. For $\mathrm{P}_{\alpha}$ and $\mathrm{P}_{\tau}$ tests, the null hypothesis of cointegration (H0:

$276 \mathrm{p}_{\mathrm{i}}=0$ for all $\left.\mathrm{i}\right)$ is tested against the alternative of cointegration $\left(\mathrm{H} 1: \mathrm{p}_{\mathrm{i}}<0\right.$ for all $\left.\mathrm{i}\right) . \mathrm{P}_{\alpha}$ and $\mathrm{P}_{\tau}$

277 tests are computed as,

278

$279 \quad \mathrm{P}_{\mathrm{a}}=\left(\sum_{\mathrm{i}=1}^{\mathrm{N}} \mathrm{L}_{\mathrm{i} 11}\right)^{-1} \sum_{\mathrm{i}=1}^{\mathrm{N}} \mathrm{L}_{\mathrm{i} 12}$

$280 \quad \mathrm{P}_{\mathrm{t}}=\hat{\sigma}^{-1}\left(\sum_{\mathrm{i}=1}^{\mathrm{N}} \mathrm{L}_{\mathrm{i} 11}\right)^{-1 / 2} \sum_{\mathrm{i}=1}^{\mathrm{N}} \mathrm{L}_{\mathrm{i} 12}$

281

282 Additionally, for $\mathrm{G}_{\alpha}$ and $\mathrm{G}_{\tau}$ tests, the null hypothesis of no cointegration is defined as $\mathrm{H} 0$ :

$283 \mathrm{p}_{\mathrm{i}}=0$ for all $\mathrm{i}$, while the alternative hypothesis of cointegration is described as $\mathrm{H} 1: \mathrm{p}_{\mathrm{i}}<0$ for at

284 least some i. $\mathrm{G}_{\alpha}$ and $\mathrm{G}_{\tau}$ test statistics are computed as shown below:

285

$286 \quad \mathrm{G}_{\mathrm{a}}=\sum_{\mathrm{i}=1}^{\mathrm{N}} \mathrm{L}_{\mathrm{i} 11}^{2} \mathrm{~L}_{\mathrm{i} 12}$

287

$\mathrm{G}_{\mathrm{t}}=\sum_{\mathrm{i}=1}^{\mathrm{N}} \hat{\sigma}_{\mathrm{i}}^{-1} \mathrm{~L}_{\mathrm{i} 11}^{-1 / 2} \mathrm{~L}_{\mathrm{i} 12}$

288

289

\subsection{Augmented Mean Group (AMG) Estimator}

290 After detecting the presence of cointegration in a panel data model, the next step is to 291 estimate long-run coefficients. Eberhard and Teal (2010) propound a two-stage panel data 292 estimator. The regression equations for this estimator are shown as

293

(i) $\quad \Delta y_{\text {it }}=b^{\prime} \Delta x_{i t}+\sum_{t=2}^{T} c_{t} D_{t}+e_{i t} \quad \rightarrow \quad \hat{c}_{t}=\hat{\mu}_{t}^{\circ}$

294

(ii) $\mathrm{y}_{\mathrm{it}}=\mathrm{a}_{\mathrm{i}}+\mathrm{b}_{\mathrm{i}}^{\prime} \mathrm{x}_{\mathrm{it}}+\mathrm{c}_{\mathrm{i}} \mathrm{t}+\mathrm{d}_{\mathrm{i}} \hat{\mu}_{\mathrm{t}}^{\circ}+\mathrm{e}_{\mathrm{it}} \quad \rightarrow \quad \hat{\mathrm{b}}_{\mathrm{AMG}}=\mathrm{N}^{-1} \sum_{\mathrm{i}=1}^{\mathrm{N}} \hat{\mathrm{b}}_{\mathrm{i}}$ 
295 In the first step, a standard pooled first difference regression that incorporates T-1 dummies,

296 namely $\hat{\mu}_{t}^{0}$, is estimated. In the second step, this variable is included in N standard unit 297 regressions. The cointegration parameters of the variables in the empirical models are 298 demonstrated by $\hat{b}_{\mathrm{AMG}}$ for the panel.

299

300

\section{Empirical Findings}

301 Table 2 reports the cross-sectional dependence (CSD) and slope heterogeneity tests results

302 for the Armey curve, the traditional EKC, and composite EKC economic models.

303

Table 2: Cross-sectional Dependence and Heterogeneity Tests Results

\begin{tabular}{|c|c|c|}
\hline $\begin{array}{l}\text { Armey Curve Model } \\
\ln D I=F\left(\ln S,(\ln S)^{2}, \ln E C\right)\end{array}$ & Test statistic & p-value \\
\hline \multicolumn{3}{|l|}{ Cross-sectional dependence tests } \\
\hline LM & $7707.202 *$ & 0.000 \\
\hline $\mathrm{CD}_{\mathrm{LM}}$ & $190.960 *$ & 0.000 \\
\hline $\mathrm{CD}$ & $74.337 *$ & 0.000 \\
\hline $\mathrm{LM}_{\mathrm{adj}}$ & $119.031 *$ & 0.000 \\
\hline \multicolumn{3}{|l|}{ Heterogeneity tests } \\
\hline$\tilde{\Delta}$ & $144.166^{*}$ & 0.000 \\
\hline$\tilde{\Delta}_{a d j}$ & $42.908^{*}$ & 0.000 \\
\hline $\begin{array}{l}\text { Traditional EKC Model } \\
\ln \mathrm{CO}_{2}=F\left(\ln D I,(\ln D I)^{2}, \ln E C\right)\end{array}$ & Test statistic & p-value \\
\hline Cross-sectional dependence tests & & \\
\hline
\end{tabular}




\begin{tabular}{|c|c|c|}
\hline LM & $7162.865^{*}$ & 0.000 \\
\hline $\mathrm{CD}_{\mathrm{LM}}$ & $119.963^{*}$ & 0.000 \\
\hline $\mathrm{CD}$ & $52.835^{*}$ & 0.000 \\
\hline $\mathrm{LM}_{\mathrm{adj}}$ & $252.897 *$ & 0.000 \\
\hline Heterogeneity tests & & \\
\hline$\tilde{\Delta}$ & $1525.583 *$ & 0.000 \\
\hline$\tilde{\Delta}_{a d j}$ & $44.414^{*}$ & 0.000 \\
\hline $\begin{array}{l}\text { Composite EKC Model } \\
\ln \mathrm{CO}_{2}=F\left[\left(\ln S+(\ln S)^{2}\right),\right. \\
\left.\left(\ln S+(\ln S)^{2}\right)^{2}, \ln E C\right]\end{array}$ & Test statistic & p-value \\
\hline Cross-sectional dependence tests & & \\
\hline LM & $6429.641 *$ & 0.000 \\
\hline $\mathrm{CD}_{\mathrm{LM}}$ & $105.150^{*}$ & 0.000 \\
\hline $\mathrm{CD}$ & $48.781^{*}$ & 0.000 \\
\hline $\mathrm{LM}_{\mathrm{adj}}$ & $216.052 *$ & 0.000 \\
\hline Heterogeneity tests & & \\
\hline$\tilde{\Delta}$ & $741.817^{*}$ & 0.000 \\
\hline$\tilde{\Delta}_{a d j}$ & $56.913 *$ & 0.000 \\
\hline
\end{tabular}

Note: * indicates $1 \%$ statistical significance.

306

307 Test results in Table 2 indicate that the null hypothesis of CSD is rejected at the $1 \%$ level 308 of significance. This means all series of the models contains CSD and a shock in one of the 309 US states can impact other US states. Furthermore, the null hypothesis of slope homogeneity 310 can be rejected by both tests for all models. This means that US states have specific 
311 characteristics in terms of the Armey and the EKC hypotheses. The results of the covariateaugmented Dickey-Fuller $(C A D F)$ unit root test are reported in Table 3.

Table 3: CADF Unit Root Test

\begin{tabular}{|c|c|c|}
\hline \multirow[t]{2}{*}{ Variable } & \multicolumn{2}{|c|}{ Test statistic } \\
\hline & Level & First difference \\
\hline $\operatorname{lnDI}$ & -1.766 & $-2.213 * *$ \\
\hline $\ln S$ & -2.026 & $-2.174 * *$ \\
\hline$(\ln S)^{2}$ & -2.022 & $-2.170 * *$ \\
\hline $\operatorname{lnCO} C_{2}$ & -1.423 & $-2.342^{*}$ \\
\hline$(\operatorname{lnDI})^{2}$ & -1.762 & $-2.225 * *$ \\
\hline$\left(\ln S+(\ln S)^{2}\right)$ & -2.023 & $-2.170 * *$ \\
\hline$\left(\ln S+(\ln S)^{2}\right)^{2}$ & -2.015 & $-2.166 * *$ \\
\hline $\operatorname{lnEC}$ & -1.008 & $-2.324 * *$ \\
\hline
\end{tabular}

Statistical significance.

320 Test results in Table 3 indicate that all variables are integrated of order one (I(1)). This

321 means that series are stationary at first differences. Hence, cointegration relationships in the models can be examined via the Westerlund (2007) panel cointegration test. The results of this test are reported in Table 4. 
326

327 328

329 As seen in Table 4, Gt test statistic indicates there is a cointegration relationship in the 330 Armey curve model, while Gt and Pt test statistics explore whether cointegration exists in 331 the EKC model. Besides, Gt, Pt, and Pa test statistics show there is cointegration in the 332 composite model. Hence, the Westerlund (2007) panel cointegration test implies there is a 333 cointegration relationship in all models and the long-run coefficients of the independent 334 variables in the models can be estimated via the AMG estimator. Test results of the AMG 335

Note: * and ** indicate $1 \%$ and 5\% statistical significances, respectively. $\mathrm{G}_{\mathrm{t}}$ and $\mathrm{G}_{\mathrm{a}}$ denote group mean statistics, while $\mathrm{P}_{\mathrm{t}}$ and $\mathrm{P}_{\mathrm{a}}$ denote panel statistics. estimator test results are reported in Table 5.

\begin{tabular}{|l|c|c|c|c|}
\hline & $\mathrm{G}_{\mathrm{t}}$ & $\mathrm{G}_{\mathrm{a}}$ & $\mathrm{P}_{\mathrm{t}}$ & $\mathrm{P}_{\mathrm{a}}$ \\
\hline Armey Curve Model & - & - & $-4.075^{*}$ & -2.957 \\
$\operatorname{lnDI}=\mathrm{F}\left(\operatorname{lnS},(\operatorname{lnS})^{2}, \mathrm{EC}\right)$ & $2.761^{*}$ & 0.937 & & \\
\hline Traditional EKC Model & - & - & $-12.905^{*}$ & -4.625 \\
$\operatorname{lnCO}_{2}=\mathrm{F}\left(\operatorname{lnDI},(\operatorname{lnDI})^{2}, \mathrm{EC}\right)$ & $2.221^{*}$ & 5.242 & & \\
\hline Composite EKC Model & - & - & $-13.408^{*}$ & $-6.038^{* *}$ \\
$\operatorname{lnCO}_{2}=\mathrm{F}\left[\left(\operatorname{lnS}+(\operatorname{lnS})^{2}\right),\left(\operatorname{lnS}+(\operatorname{lnS})^{2}\right)^{2}, \mathrm{EC}\right]$ & $2.114^{*}$ & 6.396 & & \\
\hline
\end{tabular}


Table 5: AMG Estimator Results

\begin{tabular}{|c|c|c|c|c|c|c|c|c|c|}
\hline \multirow[t]{2}{*}{ State } & \multicolumn{3}{|c|}{ Armey Curve Model } & \multicolumn{3}{|c|}{ Traditional EKC Model } & \multicolumn{3}{|c|}{ Composite EKC Model } \\
\hline & $\operatorname{lnS}$ & $(\operatorname{lnS})^{2}$ & $\operatorname{lnEC}$ & $\operatorname{lnDI}$ & $(\operatorname{lnDI})^{2}$ & $\operatorname{lnEC}$ & $\left(\operatorname{lnS}+(\operatorname{lnS})^{2}\right)$ & $\left(\ln S+(\ln S)^{2}\right)^{2}$ & $\operatorname{lnEC}$ \\
\hline Alabama & $\begin{array}{l}1.111 \\
{[1.39]}\end{array}$ & $\begin{array}{l}-0.031 \\
{[-1.28]}\end{array}$ & $\begin{array}{l}0.037 \\
{[0.52]}\end{array}$ & $\begin{array}{l}2.494 \\
{[0.85]}\end{array}$ & $\begin{array}{l}-0.123 \\
{[-0.84]}\end{array}$ & $\begin{array}{l}0.580 * \\
{[4.25]}\end{array}$ & $\begin{array}{l}-0.002 \\
{[-0.07]}\end{array}$ & $\begin{array}{l}0.001 \\
{[0.11]}\end{array}$ & $\begin{array}{l}0.638^{*} \\
{[4.25]}\end{array}$ \\
\hline Alaska & $\begin{array}{l}-1.566 \\
{[-0.44]}\end{array}$ & $\begin{array}{l}0.053 \\
{[0.48]}\end{array}$ & $\begin{array}{l}-0.225 * * \\
{[-2.26]}\end{array}$ & $\begin{array}{l}-2.477 \\
{[-1.57]}\end{array}$ & $\begin{array}{l}0.122 \\
{[1.60]}\end{array}$ & $\begin{array}{l}0.977 * \\
{[20.34]}\end{array}$ & $\begin{array}{l}0.003 \\
{[0.11]}\end{array}$ & $\begin{array}{l}-0.001 \\
{[-0.06]}\end{array}$ & $\begin{array}{l}0.948^{*} \\
{[16.52]}\end{array}$ \\
\hline Arizona & $\begin{array}{l}-1.432 * * * \\
{[-1.89]}\end{array}$ & $\begin{array}{l}0.046 * * \\
{[2.07]}\end{array}$ & $\begin{array}{l}0.635^{*} \\
{[5.49]}\end{array}$ & $\begin{array}{l}-13.361^{*} \\
{[-4.14]}\end{array}$ & $\begin{array}{l}0.659^{*} \\
{[4.11]}\end{array}$ & $\begin{array}{l}-0.839 * * \\
{[-2.53]}\end{array}$ & $\begin{array}{l}-0.097 * \\
{[-3.64]}\end{array}$ & $\begin{array}{l}0.001 * \\
{[3.62]}\end{array}$ & $\begin{array}{l}-0.409 \\
{[-1.12]}\end{array}$ \\
\hline Arkansas & $\begin{array}{l}-0.542 \\
{[-0.62]}\end{array}$ & $\begin{array}{l}0.020 \\
{[0.74]}\end{array}$ & $\begin{array}{l}-0.048 \\
{[-0.44]}\end{array}$ & $\begin{array}{l}1.700 \\
{[0.43]}\end{array}$ & $\begin{array}{l}-0.085 \\
{[-0.43]}\end{array}$ & $\begin{array}{l}0.752^{*} \\
{[3.37]}\end{array}$ & $\begin{array}{l}-0.011 \\
{[-0.30]}\end{array}$ & $\begin{array}{l}0.001 \\
{[0.29]}\end{array}$ & $\begin{array}{l}0.874 * \\
{[3.83]}\end{array}$ \\
\hline California & $\begin{array}{l}-4.548 * \\
{[-6.67]}\end{array}$ & $\begin{array}{l}0.123^{*} \\
{[6.79]}\end{array}$ & $\begin{array}{l}0.298^{*} \\
{[3.57]}\end{array}$ & $\begin{array}{l}-6.002^{*} \\
{[-2.99]}\end{array}$ & $\begin{array}{l}0.290^{*} \\
{[2.98]}\end{array}$ & $\begin{array}{l}0.629^{*} \\
{[3.36]}\end{array}$ & $\begin{array}{l}-0.055 * * \\
{[-2.03]}\end{array}$ & $\begin{array}{l}0.001 * * \\
{[2.02]}\end{array}$ & $\begin{array}{l}0.645^{*} \\
{[2.74]}\end{array}$ \\
\hline Colorado & $\begin{array}{l}3.986^{*} \\
{[4.30]}\end{array}$ & $\begin{array}{l}-0.121^{*} \\
{[-4.21]}\end{array}$ & $\begin{array}{l}-0.422 * \\
{[-2.90]}\end{array}$ & $\begin{array}{l}-3.059^{*} \\
{[-3.59]}\end{array}$ & $\begin{array}{l}0.146^{*} \\
{[3.50]}\end{array}$ & $\begin{array}{l}1.030 * \\
{[13.46]}\end{array}$ & $\begin{array}{l}-0.022 * * \\
{[-2.10]}\end{array}$ & $\begin{array}{l}0.001 * * \\
{[1.97]}\end{array}$ & $\begin{array}{l}1.086^{*} \\
{[11.38]}\end{array}$ \\
\hline Connecticut & $\begin{array}{l}5.369 * * \\
{[2.13]}\end{array}$ & $\begin{array}{l}-0.158 * * \\
{[-2.12]}\end{array}$ & $\begin{array}{l}-0.301 * * * \\
{[-1.94]}\end{array}$ & $\begin{array}{l}-2.071 \\
{[-0.60]}\end{array}$ & $\begin{array}{l}0.096 \\
{[0.58]}\end{array}$ & $\begin{array}{l}0.843 * \\
{[3.98]}\end{array}$ & $\begin{array}{l}-0.036 \\
{[-1.00]}\end{array}$ & $\begin{array}{l}0.001 \\
{[0.96]}\end{array}$ & $\begin{array}{l}0.866^{*} \\
{[4.59]}\end{array}$ \\
\hline Delaware & 2.431 & -0.080 & 0.482 & $-25.291 *$ & $1.221^{*}$ & $1.071^{*}$ & $-0.212 *$ & $0.001^{*}$ & $1.248^{*}$ \\
\hline
\end{tabular}




\begin{tabular}{|c|c|c|c|c|c|c|c|c|c|}
\hline & [1.32] & {$[-1.27]$} & [2.35] & {$[-4.27]$} & [4.21] & [5.12] & {$[-3.68]$} & [3.56] & [4.47] \\
\hline Florida & $\begin{array}{l}-2.779 * \\
{[-3.97]}\end{array}$ & $\begin{array}{l}0.081 * \\
{[4.05]}\end{array}$ & $\begin{array}{l}0.419 * \\
{[5.49]}\end{array}$ & $\begin{array}{l}0.501 \\
{[0.746]}\end{array}$ & $\begin{array}{l}-0.025 \\
{[-0.33]}\end{array}$ & $\begin{array}{l}1.127 * \\
{[6.66]}\end{array}$ & $\begin{array}{l}0.184 \\
{[1.64]}\end{array}$ & $\begin{array}{l}-0.001 \\
{[-1.64]}\end{array}$ & $\begin{array}{l}1.097 * \\
{[6.61]}\end{array}$ \\
\hline Georgia & $\begin{array}{l}4.507 * \\
{[3.32]}\end{array}$ & $\begin{array}{l}-0.137 * \\
{[-3.42]}\end{array}$ & $\begin{array}{l}0.325^{* *} \\
{[2.50]}\end{array}$ & $\begin{array}{l}-7.821 * * \\
{[-2.46]}\end{array}$ & $\begin{array}{l}0.385^{* *} \\
{[2.43]}\end{array}$ & $\begin{array}{l}1.022 * \\
{[5.13]}\end{array}$ & $\begin{array}{l}-0.124 * \\
{[-4.94]}\end{array}$ & $\begin{array}{l}0.001^{*} \\
{[4.91]}\end{array}$ & $\begin{array}{l}1.250^{*} \\
{[7.24]}\end{array}$ \\
\hline Hawaii & $\begin{array}{l}-6.899^{*} \\
{[-7.51]}\end{array}$ & $\begin{array}{l}0.230^{*} \\
{[7.93]}\end{array}$ & $\begin{array}{l}0.243 * \\
{[4.91]}\end{array}$ & $\begin{array}{l}6.759 * \\
{[3.15]}\end{array}$ & $\begin{array}{l}-0.326^{*} \\
{[-3.12]}\end{array}$ & $\begin{array}{l}1.075^{*} \\
{[25.88]}\end{array}$ & $\begin{array}{l}-0.014 \\
{[-0.67]}\end{array}$ & $\begin{array}{l}0.001 \\
{[0.80]}\end{array}$ & $\begin{array}{l}1.023 * \\
{[22.96]}\end{array}$ \\
\hline Idaho & $\begin{array}{l}1.281 * * * \\
{[1.93]}\end{array}$ & $\begin{array}{l}-0.046^{* * *} \\
{[-2.04]}\end{array}$ & $\begin{array}{l}0.082 \\
{[0.86]}\end{array}$ & $\begin{array}{l}-5.724 * * * \\
{[-1.88]}\end{array}$ & $\begin{array}{l}0.294 * * * \\
{[1.92]}\end{array}$ & $\begin{array}{l}0.910^{*} \\
{[5.99]}\end{array}$ & $\begin{array}{l}0.032 \\
{[0.88]}\end{array}$ & $\begin{array}{l}-0.001 \\
{[-0.84]}\end{array}$ & $\begin{array}{l}0.676^{*} \\
{[2.97]}\end{array}$ \\
\hline Illinois & $\begin{array}{l}2.142 * \\
{[3.06]}\end{array}$ & $\begin{array}{l}-0.063^{*} \\
{[-3.12]}\end{array}$ & $\begin{array}{l}0.106 \\
{[0.75]}\end{array}$ & $\begin{array}{l}5.492 * * \\
{[2.31]}\end{array}$ & $\begin{array}{l}-0.261 * * \\
{[-2.25]}\end{array}$ & $\begin{array}{l}1.068^{*} \\
{[4.29]}\end{array}$ & $\begin{array}{l}-0.020 \\
{[-0.75]}\end{array}$ & $\begin{array}{l}0.001 \\
{[0.88]}\end{array}$ & $\begin{array}{l}1.129 * \\
{[4.90]}\end{array}$ \\
\hline Indiana & $\begin{array}{l}3.088^{* *} \\
{[2.39]}\end{array}$ & $\begin{array}{l}-0.092 * * \\
{[-2.34]}\end{array}$ & $\begin{array}{l}-0.204 \\
{[-1.36]}\end{array}$ & $\begin{array}{l}0.785 \\
{[0.39]}\end{array}$ & $\begin{array}{l}-0.042 \\
{[-0.42]}\end{array}$ & $\begin{array}{l}0.786^{*} \\
{[4.37]}\end{array}$ & $\begin{array}{l}-0.040^{* * *} \\
{[-1.79]}\end{array}$ & $\begin{array}{l}0.001 * * * \\
{[1.78]}\end{array}$ & $\begin{array}{l}0.725^{*} \\
{[4.34]}\end{array}$ \\
\hline Iowa & $\begin{array}{l}0.334 \\
{[0.47]}\end{array}$ & $\begin{array}{l}-0.011 \\
{[-0.51]}\end{array}$ & $\begin{array}{l}0.242 * * \\
{[2.39]}\end{array}$ & $\begin{array}{l}1.679 \\
{[0.70]}\end{array}$ & $\begin{array}{l}-0.091 \\
{[-0.77]}\end{array}$ & $\begin{array}{l}1.181 * \\
{[7.15]}\end{array}$ & $\begin{array}{l}0.145 \\
{[0.33]}\end{array}$ & $\begin{array}{l}-0.001 \\
{[-0.38]}\end{array}$ & $\begin{array}{l}1.108^{*} \\
{[6.70]}\end{array}$ \\
\hline Kansas & $\begin{array}{l}-2.797 * * \\
{[-2.51]}\end{array}$ & $\begin{array}{l}0.089 * * \\
{[2.51]}\end{array}$ & $\begin{array}{l}0.008 \\
{[0.03]}\end{array}$ & $\begin{array}{l}3.659 \\
{[1.29]}\end{array}$ & $\begin{array}{l}-0.176 \\
{[-1.26]}\end{array}$ & $\begin{array}{l}1.404 * \\
{[5.98]}\end{array}$ & $\begin{array}{l}0.027 \\
{[0.97]}\end{array}$ & $\begin{array}{l}-0.001 \\
{[-0.87]}\end{array}$ & $\begin{array}{l}1.359^{*} \\
{[6.00]}\end{array}$ \\
\hline Kentucky & $2.105^{*}$ & $-0.060^{*}$ & $-0.071^{*}$ & $6.381 * *$ & $-0.323 * *$ & $0.671^{*}$ & $0.054 * * *$ & $-0.001 * * *$ & $0.728^{*}$ \\
\hline
\end{tabular}




\begin{tabular}{|c|c|c|c|c|c|c|c|c|c|}
\hline & [6.68] & {$[-6.31]$} & {$[-2.94]$} & [2.11] & {$[-2.13]$} & {$[4.06]$} & [1.69] & {$[-1.72]$} & {$[4.22]$} \\
\hline Louisiana & $\begin{array}{l}-0.154 \\
{[-0.17]}\end{array}$ & $\begin{array}{l}0.012 \\
{[0.46]}\end{array}$ & $\begin{array}{l}-0.065 \\
{[-0.82]}\end{array}$ & $\begin{array}{l}-3.901 * \\
{[-2.62]}\end{array}$ & $\begin{array}{l}0.197 * \\
{[2.65]}\end{array}$ & $\begin{array}{l}0.878^{*} \\
{[10.61]}\end{array}$ & $\begin{array}{l}-0.044 * \\
{[-3.56]}\end{array}$ & $\begin{array}{l}0.001 * \\
{[3.69]}\end{array}$ & $\begin{array}{l}0.814^{*} \\
{[12.81]}\end{array}$ \\
\hline Maine & $\begin{array}{l}\text { 3.091* } \\
{[3.11]}\end{array}$ & $\begin{array}{l}-0.094 * \\
{[-2.93]}\end{array}$ & $\begin{array}{l}-0.205^{* *} \\
{[-2.54]}\end{array}$ & $\begin{array}{l}0.257 \\
{[0.05]}\end{array}$ & $\begin{array}{l}-0.011 \\
{[-0.04]}\end{array}$ & $\begin{array}{l}0.781 \\
{[0.23]}\end{array}$ & $\begin{array}{l}0.133 * * \\
{[1.98]}\end{array}$ & $\begin{array}{l}-0.001 * * \\
{[-1.96]}\end{array}$ & $\begin{array}{l}-0.205 \\
{[-0.65]}\end{array}$ \\
\hline Maryland & $\begin{array}{l}-1.604 \\
{[-1.05]}\end{array}$ & $\begin{array}{l}0.053 \\
{[1.21]}\end{array}$ & $\begin{array}{l}0.379 * \\
{[3.36]}\end{array}$ & $\begin{array}{l}-2.522 \\
{[-1.04]}\end{array}$ & $\begin{array}{l}0.117 \\
{[1.00]}\end{array}$ & $\begin{array}{l}0.604 * \\
{[2.77]}\end{array}$ & $\begin{array}{l}-0.051 * * * \\
{[-1.74]}\end{array}$ & $\begin{array}{l}0.001 * * * \\
{[1.70]}\end{array}$ & $\begin{array}{l}0.570^{*} \\
{[2.68]}\end{array}$ \\
\hline Massachusetts & $\begin{array}{l}-0.006 \\
{[-0.0019}\end{array}$ & $\begin{array}{l}-0.001 \\
{[-0.004]}\end{array}$ & $\begin{array}{l}-0.061 \\
{[-0.46]}\end{array}$ & $\begin{array}{l}-7.010 * \\
{[-3.10]}\end{array}$ & $\begin{array}{l}0.331 * \\
{[3.02]}\end{array}$ & $\begin{array}{l}0.422 * * * \\
{[1.79]}\end{array}$ & $\begin{array}{l}-0.023 \\
{[-0.61]}\end{array}$ & $\begin{array}{l}0.001 \\
{[0.50]}\end{array}$ & $\begin{array}{l}0.285 \\
{[1.11]}\end{array}$ \\
\hline Michigan & $\begin{array}{l}-0.248 \\
{[-0.10]}\end{array}$ & $\begin{array}{l}0.012 \\
{[0.17]}\end{array}$ & $\begin{array}{l}0.363 * * \\
{[2.53]}\end{array}$ & $\begin{array}{l}4.175^{* *} \\
{[2.31]}\end{array}$ & $\begin{array}{l}-0.213^{* *} \\
{[-2.38]}\end{array}$ & $\begin{array}{l}0.769^{*} \\
{[7.51]}\end{array}$ & $\begin{array}{l}0.071^{*} \\
{[2.76]}\end{array}$ & $\begin{array}{l}-0.001 * \\
{[-2.84]}\end{array}$ & $\begin{array}{l}0.608^{*} \\
{[5.66]}\end{array}$ \\
\hline Minnesota & $\begin{array}{l}1.840 \text { *** } \\
{[1.81]}\end{array}$ & $\begin{array}{l}-0.053^{*} \\
{[-1.75]}\end{array}$ & $\begin{array}{l}0.060 \\
{[0.54]}\end{array}$ & $\begin{array}{l}0.154 \\
{[0.08]}\end{array}$ & $\begin{array}{l}-0.011 \\
{[-0.13]}\end{array}$ & $\begin{array}{l}0.859^{*} \\
{[5.44]}\end{array}$ & $\begin{array}{l}0.001 \\
{[0.03]}\end{array}$ & $\begin{array}{l}-0.001 \\
{[-0.08]}\end{array}$ & $\begin{array}{l}0.848^{*} \\
{[5.13]}\end{array}$ \\
\hline Mississippi & $\begin{array}{l}1.944 * \\
{[3.05]}\end{array}$ & $\begin{array}{l}-0.054 * \\
{[-2.66]}\end{array}$ & $\begin{array}{l}-0.228 * * \\
{[-2.49]}\end{array}$ & $\begin{array}{l}-2.903 \\
{[-0.70]}\end{array}$ & $\begin{array}{l}0.160 \\
{[0.76]}\end{array}$ & $\begin{array}{l}0.613 * * * \\
{[1.79]}\end{array}$ & $\begin{array}{l}0.001 \\
{[0.04]}\end{array}$ & $\begin{array}{l}0.001 \\
{[0.09]}\end{array}$ & $\begin{array}{l}0.542 \\
{[1.51]}\end{array}$ \\
\hline Missouri & $\begin{array}{l}2.154^{*} \\
{[3.71]}\end{array}$ & $\begin{array}{l}-0.062^{*} \\
{[-3.49]}\end{array}$ & $\begin{array}{l}-0.096^{* * *} \\
{[-1.96]}\end{array}$ & $\begin{array}{l}.494 \\
{[1.09]}\end{array}$ & $\begin{array}{l}-0.215 \\
{[-1.05]}\end{array}$ & $\begin{array}{l}0.597^{* *} \\
{[2.18]}\end{array}$ & $\begin{array}{l}0.007 \\
{[0.19]}\end{array}$ & $\begin{array}{l}-0.001 \\
{[-0.11]}\end{array}$ & $\begin{array}{l}0.714^{*} \\
{[2.72]}\end{array}$ \\
\hline Montana & $-5.657^{*}$ & $0.189 *$ & 0.077 & $-12.478^{*}$ & $0.629^{*}$ & 0.156 & $-0.120^{*}$ & $0.001^{*}$ & 0.234 \\
\hline
\end{tabular}




\begin{tabular}{|c|c|c|c|c|c|c|c|c|c|}
\hline & {$[-5.85]$} & [5.95] & [1.00] & {$[-3.49]$} & [3.51] & {$[1.06]$} & {$[-2.81]$} & [2.87] & [1.51] \\
\hline Nebraska & $\begin{array}{l}-1.397 \\
{[-1.38]}\end{array}$ & $\begin{array}{l}0.047 \\
{[1.39]}\end{array}$ & $\begin{array}{l}0.302 * \\
{[2.98]}\end{array}$ & $\begin{array}{l}3.030 \\
{[1.04]}\end{array}$ & $\begin{array}{l}-0.149 \\
{[-1.05]}\end{array}$ & $\begin{array}{l}0.857^{*} \\
{[4.96]}\end{array}$ & $\begin{array}{l}0.061 * * * \\
{[1.76]}\end{array}$ & $\begin{array}{l}-0.001 * * * \\
{[-1.77]}\end{array}$ & $\begin{array}{l}0.899^{*} \\
{[6.17]}\end{array}$ \\
\hline Nevada & $\begin{array}{l}0.669 \\
{[1.07]}\end{array}$ & $\begin{array}{l}-0.018 \\
{[-0.90]}\end{array}$ & $\begin{array}{l}0.701 * \\
{[7.87]}\end{array}$ & $\begin{array}{l}-1.554 \\
{[-0.28]}\end{array}$ & $\begin{array}{l}0.057 \\
{[0.21]}\end{array}$ & $\begin{array}{l}0.976^{*} \\
{[4.02]}\end{array}$ & $\begin{array}{l}0.020 \\
{[0.51]}\end{array}$ & $\begin{array}{l}-0.001 \\
{[-0.71]}\end{array}$ & $\begin{array}{l}0.506^{* * *} \\
{[1.88]}\end{array}$ \\
\hline New Hampshire & $\begin{array}{l}1.204 \\
{[1.30]}\end{array}$ & $\begin{array}{l}-0.038 \\
{[-1.22]}\end{array}$ & $\begin{array}{l}0.297 * \\
{[2.61]}\end{array}$ & $\begin{array}{l}-7.791 * * * \\
{[-1.78]}\end{array}$ & $\begin{array}{l}0.385 * * * \\
{[1.80]}\end{array}$ & $\begin{array}{l}0.258 \\
{[0.97]}\end{array}$ & $\begin{array}{l}-0.096^{* *} \\
{[-2.49]}\end{array}$ & $\begin{array}{l}0.001 * \\
{[2.61]}\end{array}$ & $\begin{array}{l}0.356 \\
{[1.49]}\end{array}$ \\
\hline New Jersey & $\begin{array}{l}1.861 * \\
{[2.70]}\end{array}$ & $\begin{array}{l}-0.054 * \\
{[-2.76]}\end{array}$ & $\begin{array}{l}-0.090 * * * \\
{[-1.76]}\end{array}$ & $\begin{array}{l}-2.918 \\
{[-1.25]}\end{array}$ & $\begin{array}{l}0.140 \\
{[1.24]}\end{array}$ & $\begin{array}{l}1.154^{*} \\
{[7.78]}\end{array}$ & $\begin{array}{l}0.013 \\
{[0.43]}\end{array}$ & $\begin{array}{l}-0.001 \\
{[-0.45]}\end{array}$ & $\begin{array}{l}1.144 * \\
{[7.73]}\end{array}$ \\
\hline New Mexico & $\begin{array}{l}0.314 \\
{[0.79]}\end{array}$ & $\begin{array}{l}-0.003 \\
{[-0.23]}\end{array}$ & $\begin{array}{l}-0.004 \\
{[-0.05]}\end{array}$ & $\begin{array}{l}-3.069 \\
{[-0.82]}\end{array}$ & $\begin{array}{l}0.147 \\
{[0.79]}\end{array}$ & $\begin{array}{l}0.300 \\
{[1.31]}\end{array}$ & $\begin{array}{l}-0.028 \\
{[-1.19]}\end{array}$ & $\begin{array}{l}0.001 \\
{[1.12]}\end{array}$ & $\begin{array}{l}0.312 \\
{[1.53]}\end{array}$ \\
\hline New York & $\begin{array}{l}-5.228^{*} \\
{[-3.61]}\end{array}$ & $\begin{array}{l}0.138^{*} \\
{[3.49]}\end{array}$ & $\begin{array}{l}-0.048 \\
{[-0.47]}\end{array}$ & $\begin{array}{l}-5.999^{*} \\
{[-3.40]}\end{array}$ & $\begin{array}{l}0.284 * \\
{[3.31]}\end{array}$ & $\begin{array}{l}0.940^{*} \\
{[8.58]}\end{array}$ & $\begin{array}{l}-0.081^{*} \\
{[-3.98]}\end{array}$ & $\begin{array}{l}0.001^{*} \\
{[3.85]}\end{array}$ & $\begin{array}{l}1.010^{*} \\
{[11.09]}\end{array}$ \\
\hline North Carolina & $\begin{array}{l}1.376 \\
{[0.81]}\end{array}$ & $\begin{array}{l}-0.042 \\
{[-0.85]}\end{array}$ & $\begin{array}{l}0.187 \\
{[1.08]}\end{array}$ & $\begin{array}{l}-0.281 \\
{[-0.14]}\end{array}$ & $\begin{array}{l}0.015 \\
{[0.15]}\end{array}$ & $\begin{array}{l}1.404 * \\
{[7.47]}\end{array}$ & $\begin{array}{l}0.003 \\
{[0.14]}\end{array}$ & $\begin{array}{l}-0.001 \\
{[-0.10]}\end{array}$ & $\begin{array}{l}1.318^{*} \\
{[6.12]}\end{array}$ \\
\hline North Dakota & $\begin{array}{l}2.954 \\
{[0.99]}\end{array}$ & $\begin{array}{l}-0.088 \\
{[-0.93]}\end{array}$ & $\begin{array}{l}0.586^{* *} \\
{[2.19]}\end{array}$ & $\begin{array}{l}-0.487 \\
{[-0.40]}\end{array}$ & $\begin{array}{l}0.026 \\
{[0.42]}\end{array}$ & $\begin{array}{l}0.260 * * \\
{[2.34]}\end{array}$ & $\begin{array}{l}0.037 * \\
{[2.68]}\end{array}$ & $\begin{array}{l}-0.001 * \\
{[-2.77]}\end{array}$ & $\begin{array}{l}0.440 * \\
{[4.86]}\end{array}$ \\
\hline Ohio & 1.775 & -0.056 & -0.044 & -0.632 & 0.030 & $0.319^{* * *}$ & $-0.080 * *$ & $0.001^{* *}$ & $0.516^{*}$ \\
\hline
\end{tabular}




\begin{tabular}{|c|c|c|c|c|c|c|c|c|c|}
\hline & [1.33] & {$[-1.44]$} & {$[-0.37]$} & {$[-0.21]$} & {$[0.21]$} & {$[1.70]$} & {$[-2.19]$} & {$[2.21]$} & [2.78] \\
\hline Oklahoma & $\begin{array}{l}-2.579 * * * \\
{[-1.72]}\end{array}$ & $\begin{array}{l}0.088 * * * \\
{[1.94]}\end{array}$ & $\begin{array}{l}0.845^{* * *} \\
{[2.52]}\end{array}$ & $\begin{array}{l}-4.089 \\
{[-1.51]}\end{array}$ & $\begin{array}{l}0.206 \\
{[1.52]}\end{array}$ & $\begin{array}{l}-0.097 \\
{[-0.29]}\end{array}$ & $\begin{array}{l}-0.037 \\
{[-0.84]}\end{array}$ & $\begin{array}{l}0.001 \\
{[0.87]}\end{array}$ & $\begin{array}{l}0.175 \\
{[0.58]}\end{array}$ \\
\hline Oregon & $\begin{array}{l}-0.981 * * \\
{[-2.07]}\end{array}$ & $\begin{array}{l}0.034 * * \\
{[2.36]}\end{array}$ & $\begin{array}{l}0.381 * \\
{[3.66]}\end{array}$ & $\begin{array}{l}-0.746 \\
{[-0.21]}\end{array}$ & $\begin{array}{l}0.043 \\
{[0.24]}\end{array}$ & $\begin{array}{l}0.446^{* *} \\
{[2.24]}\end{array}$ & $\begin{array}{l}-0.009 \\
{[-0.25]}\end{array}$ & $\begin{array}{l}0.001 \\
{[0.31]}\end{array}$ & $\begin{array}{l}0.453^{* * *} \\
{[1.82]}\end{array}$ \\
\hline Pennsylvania & $\begin{array}{l}-1.169 * \\
{[-3.23]}\end{array}$ & $\begin{array}{l}0.034^{*} \\
{[3.28]}\end{array}$ & $\begin{array}{l}0.050 \\
{[0.99]}\end{array}$ & $\begin{array}{l}0.549 \\
{[0.22]}\end{array}$ & $\begin{array}{l}-0.030 \\
{[-0.25]}\end{array}$ & $\begin{array}{l}0.432 * * \\
{[2.58]}\end{array}$ & $\begin{array}{l}-0.016 \\
{[-0.61]}\end{array}$ & $\begin{array}{l}0.001 \\
{[0.59]}\end{array}$ & $\begin{array}{l}0.437 * * \\
{[2.53]}\end{array}$ \\
\hline Rhode Island & $\begin{array}{l}0.307 \\
{[0.35]}\end{array}$ & $\begin{array}{l}-0.006 \\
{[-0.22]}\end{array}$ & $\begin{array}{l}-0.089 * * * \\
{[-1.67]}\end{array}$ & $\begin{array}{l}\text { 36.391* } \\
{[5.15]}\end{array}$ & $\begin{array}{l}-1.784 * \\
{[-5.14]}\end{array}$ & $\begin{array}{l}0.908^{*} \\
{[3.76]}\end{array}$ & $\begin{array}{l}0.536^{*} \\
{[4.11]}\end{array}$ & $\begin{array}{l}-0.001^{*} \\
{[-4.09]}\end{array}$ & $\begin{array}{l}0.672 * \\
{[2.59]}\end{array}$ \\
\hline South Carolina & $\begin{array}{l}1.293 \\
{[1.49]}\end{array}$ & $\begin{array}{l}-0.041 \\
{[-1.57]}\end{array}$ & $\begin{array}{l}0.087 \\
{[1.15]}\end{array}$ & $\begin{array}{l}1.538 \\
{[0.56]}\end{array}$ & $\begin{array}{l}-0.071 \\
{[-0.52]}\end{array}$ & $\begin{array}{l}0.236 \\
{[1.03]}\end{array}$ & $\begin{array}{l}-0.050^{* * * *} \\
{[-1.85]}\end{array}$ & $\begin{array}{l}0.001 * * \\
{[1.97]}\end{array}$ & $\begin{array}{l}0.641^{*} \\
{[2.86]}\end{array}$ \\
\hline South Dakota & $\begin{array}{l}1.338 * * * \\
{[1.81]}\end{array}$ & $\begin{array}{l}-0.044 * * * \\
{[-1.71]}\end{array}$ & $\begin{array}{l}0.439 * \\
{[5.27]}\end{array}$ & $\begin{array}{l}7.187^{*} \\
{[2.93]}\end{array}$ & $\begin{array}{l}-0.361^{*} \\
{[-2.94]}\end{array}$ & $\begin{array}{l}0.455^{*} \\
{[3.04]}\end{array}$ & $\begin{array}{l}0.115^{* *} \\
{[2.49]}\end{array}$ & $\begin{array}{l}-0.001 * * \\
{[-2.49]}\end{array}$ & $\begin{array}{l}0.395^{*} \\
{[2.69]}\end{array}$ \\
\hline Tennessee & $\begin{array}{l}5.038^{*} \\
{[5.11]}\end{array}$ & $\begin{array}{l}-0.151^{*} \\
{[-5.00]}\end{array}$ & $\begin{array}{l}-0.249 * \\
{[-3.23]}\end{array}$ & $\begin{array}{l}6.215^{* *} \\
{[2.19]}\end{array}$ & $\begin{array}{l}-0.319 * * \\
{[-2.26]}\end{array}$ & $\begin{array}{l}1.481^{*} \\
{[5.03]}\end{array}$ & $\begin{array}{l}0.081 * \\
{[2.87]}\end{array}$ & $\begin{array}{l}-0.001^{*} \\
{[-2.99]}\end{array}$ & $\begin{array}{l}1.061 * \\
{[3.96]}\end{array}$ \\
\hline Texas & $\begin{array}{l}-0.029 \\
{[-0.05]}\end{array}$ & $\begin{array}{l}0.002 \\
{[0.13]}\end{array}$ & $\begin{array}{l}0.050 \\
{[0.71]}\end{array}$ & $\begin{array}{l}-1.553 * * \\
{[-2.10]}\end{array}$ & $\begin{array}{l}0.074 * * \\
{[2.01]}\end{array}$ & $\begin{array}{l}0.908^{*} \\
{[31.22]}\end{array}$ & $\begin{array}{l}-0.003 \\
{[-0.52]}\end{array}$ & $\begin{array}{l}0.001 \\
{[0.38]}\end{array}$ & $\begin{array}{l}0.877^{*} \\
{[26.30]}\end{array}$ \\
\hline Utah & -0.659 & 0.019 & $0.251^{* * *}$ & -3.442 & 0.162 & $0.362^{* *}$ & -0.042 & 0.001 & $0.358 * * *$ \\
\hline
\end{tabular}




\begin{tabular}{|l|l|l|l|l|l|l|l|l|l|}
\hline & {$[-0.77]$} & {$[0.69]$} & {$[1.79]$} & {$[-1.61]$} & {$[1.51]$} & {$[2.22]$} & {$[-1.43]$} & {$[1.31]$} & {$[1.88]$} \\
\hline Vermont & $0.833^{* * *}$ & -0.022 & -0.038 & 4.431 & -0.220 & $0.346^{* * *}$ & 0.085 & -0.001 & $0.433^{* *}$ \\
& {$[1.92]$} & {$[-1.58]$} & {$[-0.76]$} & {$[1.10]$} & {$[-1.11]$} & {$[1.66]$} & {$[1.64]$} & {$[-1.65]$} & {$[2.03]$} \\
\hline Virginia & $-2.693^{*}$ & $0.084 *$ & $0.390^{*}$ & 2.021 & -0.100 & 0.517 & 0.053 & -0.001 & $0.592^{* * *}$ \\
& {$[-3.56]$} & {$[3.71]$} & {$[5.72]$} & {$[0.60]$} & {$[-0.61]$} & {$[1.36]$} & {$[1.36]$} & {$[1.36]$} & {$[1.66]$} \\
\hline Washington & -0.287 & 0.006 & 0.047 & -5.137 & 0.246 & $0.391^{* *}$ & 0.028 & -0.001 & 0.275 \\
& {$[-0.43]$} & {$[0.33]$} & {$[0.61]$} & {$[-1.51]$} & {$[1.47]$} & {$[2.18]$} & {$[0.53]$} & {$[-0.58]$} & {$[1.25]$} \\
\hline West Virginia & -0.691 & 0.021 & $0.188^{* * *}$ & 3.777 & -0.186 & $1.230^{*}$ & -0.004 & 0.001 & $1.073^{*}$ \\
& {$[-0.93]$} & {$[0.90]$} & {$[1.71]$} & {$[1.06]$} & {$[-1.07]$} & {$[4.15]$} & {$[-0.07]$} & {$[0.09]$} & {$[4.14]$} \\
\hline Wisconsin & $1.887 * *$ & $-0.053^{* *}$ & 0.039 & -0.628 & 0.026 & $1.303 *$ & -0.002 & 0.001 & $1.257^{*}$ \\
& {$[2.33]$} & {$[-2.18]$} & {$[0.57]$} & {$[-0.43]$} & {$[0.36]$} & {$[12.48]$} & {$[-0.013]$} & {$[0.04]$} & {$[11.20]$} \\
\hline Wyoming & 0.226 & -0.002 & $0.400^{* *}$ & -0.144 & 0.004 & $0.284^{* *}$ & $0.064 * *$ & $-0.001^{* *}$ & $0.458^{*}$ \\
& {$[0.16]$} & {$[-0.005]$} & {$[2.44]$} & {$[-0.08]$} & {$[0.05]$} & {$[2.04]$} & {$[2.16]$} & {$[-2.21]$} & {$[3.66]$} \\
\hline
\end{tabular}


340 Test results in Table 5 indicate that the Armey curve hypothesis is validated only for 15 US 341 states out of the 50, namely, Colorado, Connecticut, Georgia, Idaho, Illinois, Indiana, 342 Kentucky, Maine, Minnesota, Mississippi, Missouri, New Jersey, South Dakota, Tennessee, 343 and Wisconsin. However, the composite EKC model is significant for only 7 of them, namely, 344 Colorado, Georgia, Indiana, Kentucky, Maine, South Dakota, and Tennessee. This means that 345 it is possible to test the EKC hypothesis with the proposed methodological approach of this 346 study only for these 7 US states since the Armey curve hypothesis has been validated and the 347 composite model is significant for these states. Furthermore, the composite EKC model 348 hypothesis is validated only for Kentucky, Maine, South Dakota, and Tennessee since $\gamma<0$ 349 and $-c \beta^{2}+2 \mathrm{~b} \gamma+4 c \alpha \gamma<0$ (two inverted U-shaped curves: Case 1 in Figure 4). However, 350 the composite EKC hypothesis is not validated for Colorado, Georgia, and Indiana since $\gamma<$ 3510 and $-c \beta^{2}+2 \mathrm{~b} \gamma+4 c \alpha \gamma>0$ (inverted U-shaped Armey curve and U-shaped composite 352 EKC model in Case 2 in Figure 5). Furthermore, the maximum (optimal) state government 353 spending levels that will maximize $\mathrm{CO}_{2}$ emissions for Kentucky, Maine, South Dakota, and 354 Tennessee were calculated as $17.5 \%, 16.4 \%, 15.2 \%$ and $16.6 \%$ of real GDP per capita of these 355 states, respectively. This can be depicted in Case 1 in Figure 4. Similarly, the maximum 356 (optimal) state government spending levels that will minimize $\mathrm{CO}_{2}$ emissions for Colorado, 357 Georgia, and Indiana were calculated as $16.40 \%, 16.45$, and $16.7 \%$ of real GDP per capita of 358 these states, respectively. This can be depicted in Case 2 in Figure 5. Apart from the 359 methodological approach of this study, the traditional EKC hypothesis is validated for only 7 360 US states out of the 50 since the signs for $b$ and $c$ in Eqn. 2 are positive and negative, 361 respectively (inverted U-shaped curves). 
363 Additionally, rises in energy consumption $(E C)$ increase $\mathrm{CO}_{2}$ emissions in 41 US states out 364 of the 50 since the signs of this variable are significantly positive. Table 6 shows the curve 365 shapes of the Armey, traditional EKC, and composite EKC models. We also created US state366 level maps (in Figures 6,7, and 8) to show the validations of the Armey curve, the traditional 367 EKC, and composite EKC hypotheses. We believe that these maps will help state 368 policymakers to re-review the results of their economic and energy polices in terms of these 369 models. The Federal Government will also be enabled to re-review the states' positions based 370 on a holistic picture from these maps since the impact of the states' economics-energy policies 371 on $\mathrm{CO}_{2}$ emissions vary from one another.

373 Table 6: Curve Shapes of the Armey, EKC, and Composite Models

\begin{tabular}{|l|l|c|c|c|}
\hline \multicolumn{2}{|c|}{ State } & Traditional & Armey Curve & Composite \\
\cline { 1 - 2 } Number & Name & EKC Model & Model & EKC Model \\
\hline 1 & Alabama & - & - & - \\
\hline 2 & Alaska & - & - & - \\
\hline 3 & Arizona & U & U & U \\
\hline 4 & Arkansas & - & - & - \\
\hline 5 & California & U & U & U \\
\hline 6 & Colorado & U & $\cap$ & U \\
\hline 7 & Connecticut & - & $\cap$ & - \\
\hline 8 & Delaware & U & - & U \\
\hline 9 & Florida & - & U & - \\
\hline 10 & Georgia & $\mathrm{U}$ & $\cap$ & U \\
\hline 11 & Hawaii & $\cap$ & $\mathrm{U}$ & - \\
\hline
\end{tabular}




\begin{tabular}{|c|c|c|c|c|}
\hline 12 & Idaho & $\mathrm{U}$ & $\cap$ & - \\
\hline 13 & Illinois & $\cap$ & $\cap$ & - \\
\hline 14 & Indiana & - & $\cap$ & $\bar{U}$ \\
\hline 15 & Iowa & - & - & - \\
\hline 16 & Kansas & - & $\mathrm{U}$ & - \\
\hline 17 & Kentucky & $\cap$ & $\cap$ & $\bar{n}$ \\
\hline 18 & Louisiana & $\mathrm{U}$ & - & $\mathrm{U}$ \\
\hline 19 & Maine & - & $\cap$ & 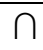 \\
\hline 20 & Maryland & & - & $\mathrm{U}$ \\
\hline 21 & Massachusetts & $\mathrm{U}$ & - & -- \\
\hline 22 & Michigan & $\bigcap$ & - & $\cap$ \\
\hline 23 & Minnesota & - & $\cap$ & - \\
\hline 24 & Mississippi & - & $\cap$ & - \\
\hline 25 & Missouri & & $\cap$ & - \\
\hline 26 & Montana & $\mathrm{U}$ & $\mathrm{U}$ & $\bar{U}$ \\
\hline 27 & Nebraska & - & - & $\cap$ \\
\hline 28 & Nevada & - & - & - \\
\hline 29 & New Hampshire & $\mathrm{U}$ & - & $\bar{U}$ \\
\hline 30 & New Jersey & - & $\cap$ & - \\
\hline 31 & New Mexico & - & & - \\
\hline 32 & New York & $\mathrm{U}$ & $\mathrm{U}$ & $\mathrm{U}$ \\
\hline 33 & North Carolina & - & - & - \\
\hline 34 & North Dakota & - & - & $\bar{n}$ \\
\hline 35 & Ohio & - & - & $\bar{U}$ \\
\hline 36 & Oklahoma & - & $\mathrm{U}$ & - \\
\hline
\end{tabular}




\begin{tabular}{|l|l|c|c|c|}
\hline 37 & Oregon & - & $\mathrm{U}$ & -374 \\
\hline 38 & Pennsylvania & - & $\mathrm{U}$ & - \\
\hline 39 & Rhode Island & $\cap$ & - & $\cap$ \\
\hline 40 & South Carolina & - & - & $\mathrm{U}$ \\
\hline 41 & South Dakota & $\cap$ & $\cap$ & $\cap$ \\
\hline 42 & Tennessee & $\cap$ & $\cap$ & $\cap$ \\
\hline 43 & Texas & $\mathrm{U}$ & - & - \\
\hline 44 & Utah & - & - & - \\
\hline 45 & Vermont & - & - & - \\
\hline 46 & Virginia & - & $\mathrm{U}$ & - \\
\hline 47 & Washington & - & - & - \\
\hline 48 & West Virginia & - & - & - \\
\hline 49 & Wisconsin & - & $\cap$ & - \\
\hline 50 & Wyoming & - & & \\
\hline
\end{tabular}

375 Note: Curve Shapes were obtained from Table 4. (U): U-shaped curve, ( $(\cap)$ :

376 Inverted U-shaped curve, (-): insignificant model (curve).

377

378

379 Figures 6, 7, and 8: US state-level Maps 


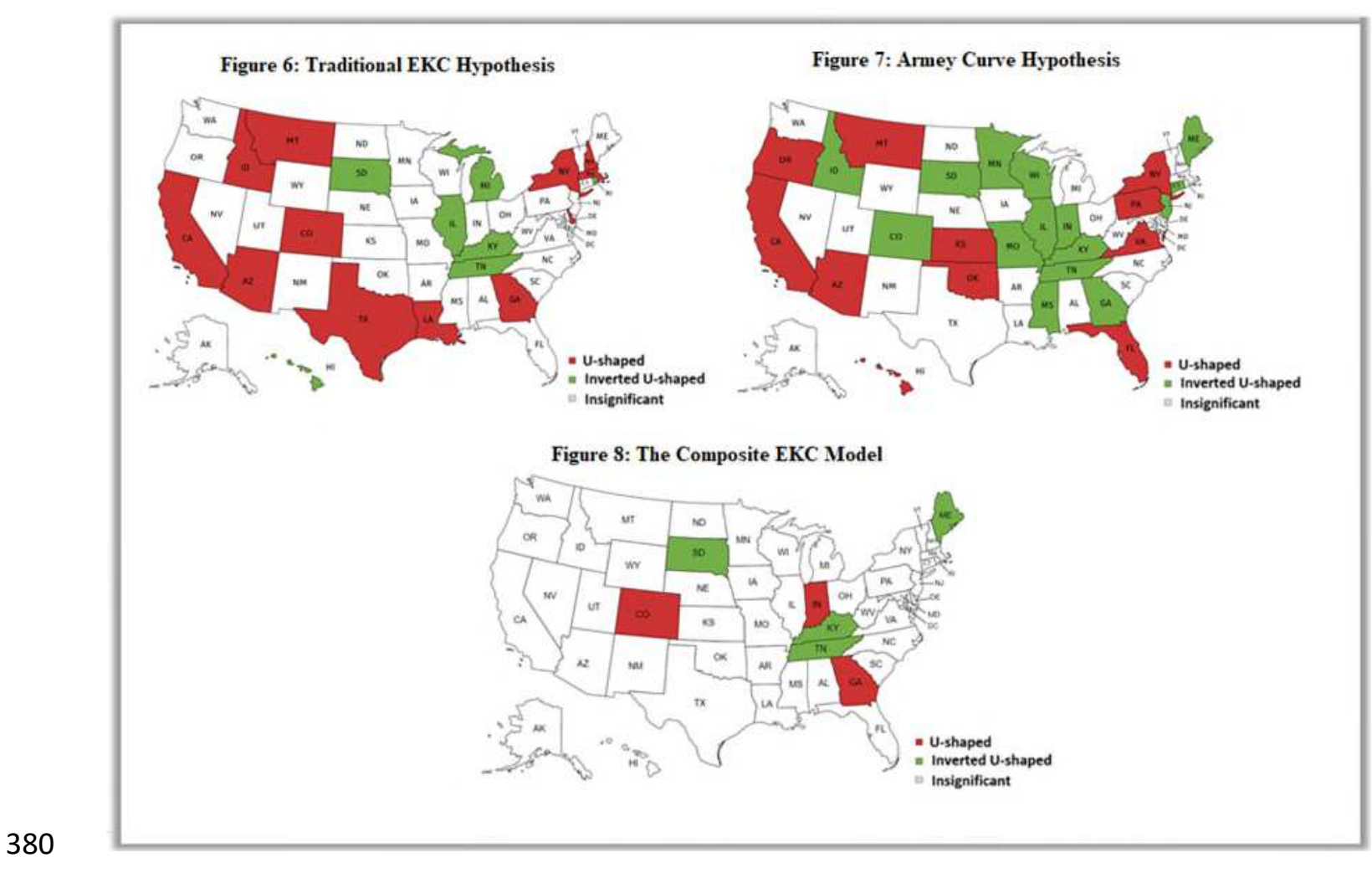

381 Note: States in green and red mean that the Armey curve, traditional EKC, and composite EKC hypotheses (models)

382 were validated and not verified, respectively. The states in white mean that these three models were

383 insignificant. Maps were created from empirical findings of the study.

\section{5. Conclusion with Policy Implications}

388 The testing methodology of this study's EKC hypothesis differs from all previous empirical 389 studies, in relevant literature, that have used traditional EKC models. This methodology 390 unifies two seemingly different but strongly interrelated hypotheses (models) into one single 391 composite model. These are the Armey curve and EKC hypotheses, which were constructed 392 on the same nonlinear mathematical propositions with inverted U-shaped curves. These two 393 hypotheses (models) also have economically interrelated-causal relationships between their 
394 independent and dependent variables. This can be explained because rising government 395 spending (based on the Armey curve hypothesis) increases real GDP per capita and, 396 consequently, the increases in real GDP per capita increase environmental degradation $\left(\mathrm{CO}_{2}\right.$ 397 emissions). In other words, the Armey curve model's dependent variable is the independent 398 variable of the EKC model. Therefore, both mathematically and economically, we can create 399 a single composite model, which will be derived from the individual Armey and EKC models, 400 to test the EKC hypothesis through the Armey curve hypothesis (model) for US states. This 401 methodology proposed may also allow US state policymakers to determine a single maximum 402 (optimal) spending level that will maximize or minimize $\mathrm{CO}_{2}$ emissions depending on the 403 composite model's curve shape. With this methodology, both economic policies through the 404 Armey curve, based on government spending, and energy policies through the EKC 405 hypothesis, based on real GDP per capita, can be jointly examined to a certain extent. This 406 examination may also provide state policymakers to re-consider whether their economic and 407 energy policies are compatible with each other.

409 Empirical findings indicate that the methodology proposed in this study, with its composite 410 EKC model constructed based on the Armey curve model, is capable of testing the EKC 411 hypothesis for 7 states namely, Colorado, Georgia, Indiana, Kentucky, Maine, South Dakota, 412 and Tennessee. For 4 of the 7 states, namely, Kentucky, Maine, South Dakota, and Tennessee, 413 the EKC hypothesis is validated but not for the other 3 states. But, more importantly, 414 regardless of the verification of the EKC hypothesis, with the model proposed by this study, 415 these 4 US states' policymakers will be able to determine the maximum spending levels that 416 will maximize the real GDP per capita and $\mathrm{CO}_{2}$ emissions. Hence, they will know that 
417 additional spending after this maximum threshold points will decrease environmental 418 degradation as well as real GPD per capita. This outcome, of course, may create a dilemma 419 for the policymakers who will have to choose between lower economic growth and cleaner 420 environment. However, they can determine a golden ratio that will ensure them sustainable421 compatible economic and energy policies at a lower cost. From the same methodological 422 context, the policymakers of Colorado, Georgia, and Indiana will be able to determine their 423 maximum spending levels that will maximize the real GDP per capita and minimize $\mathrm{CO}_{2}$ 424 emissions. Hence, they will know that additional spending after this maximum threshold 425 points will decrease real GDP per capita and increase $\mathrm{CO}_{2}$ emissions. This outcome may give 426 them an ideal (optimal) maximum spending level rather than creating a dilemma, as was the 427 case with Kentucky, Maine, South Dakota, and Tennessee. Therefore, policymakers may slow 428 down their economies with no more spending for compatible-sustainable economic and 429 energy policies. Empirical findings of the models reveal that the maximum spending levels 430 that will maximize or minimize real GDP per capita and $\mathrm{CO}_{2}$ emissions are between $15.2 \%$ $43117.5 \%$ of the states' real GDP per capita. Additionally, the map created in Figure 7 clearly 432 shows that the Armey curve hypothesis is validated in the states mostly located in the inner 433 agricultural areas of the USA. Additional spending in these states initially increases real GDP 434 per capita until a certain point and eventually decreases it.

435 All these outcomes and interactions expected between the variables should be considered 436 based only on the proposed methodology of the study incorporating the Armey curve and the 437 traditional EKC models and not on other macroeconomic variables of the economy. The 438 findings of this study show the need for further empirical studies that will re-approach and re439 test the old and recent hypotheses-theories based on multi-dimensional-functional 
440 perspectives as we did for the EKC hypothesis. These types of approaches may enable

441 examining economic issues from a holistic point of view since macroeconomic variables

442 dynamically and causally interact with one another.

443 Dataset: $D I$ and $S$ are in USD; $C$ is million btu. Data of state government spending were 444 obtained from the Urban Institute (Urban). Data of state-level total energy consumption- $\mathrm{CO}_{2}$

445 emissions (metric million tons) and real DI were obtained from the U.S. Energy Information

446 Administration (EIA) and Data Planet, respectively.

447 Conflicts of Interest: The authors declare no conflict of interest.

448 Compliance with ethical standards

449 Competing interests: The authors declare that they have no competing interests.

450 Ethics approval and consent to participate: Not applicable.

451 Consent for publication: Not applicable

452 Funding: Not applicable

453 Availability of data and materials: Not applicable

454 Author Contributions: Conceptualization, S.O. and C.I. methodology, U.B., C.I., S.O. and

455 S.K.; investigation, R.A., M.I. and M.A.; writing - original draft preparation, S.O. C.I.,

456 U.B., writing - review and editing, S.O. C.I., U.B., S.K. R.A., M.I. and M.A.; supervision,

457 S.O. and S.K..; All authors have read and agreed to the published version of the manuscript.

458

459 References

460 Apergis N, Christou C, Gupta R (2017) Are there Environmental Kuznets Curves for US

461 state-level CO2 emissions?. Renewable and Sustainable Energy Reviews 69(C): 551$462 \quad 558$.

463 Armey D (1995) The freedom revolution: Why big government failed, why freedom works, 464 and how we will rebuild America, Washington, DC: Regnery Publishing.

465 Aslan A, Destek MA, Okumus I (2018) Bootstrap rolling window estimation approach to 466 analysis of the Environment Kuznets Curve hypothesis: evidence from the USA. 467 Environmental Science and Pollution Research 25(3): 2402-2408.

468 Barro RJ (1990) Government spending in a simple model of endogenous growth. The 469 Journal of Political Economy 98: S103-S125. 
Bastiat F (1983) Oeuvres économiques, coll. Libre échange, PUF, Paris.

Bozma G, Başar S, Eren M (2019) Investigating validation of Armey curve hypothesis for G7 countries using ARDL model. Doğuş Üniversitesi Dergisi 20(1): 4.

Breusch TS, Pagan AR (1980) The Lagrange multiplier test and its applications to model specification in econometrics. Review of Economic Studies 47(XLVII): 239-253.

Chao J, Grubel H (1998) Optimal Levels of Spending and Taxation in Canada, Chapter in How to Use the Fiscal Surplus: What is the optimum Size of Government, The Fraser Institute, Vancouver.

Colombier C (2009) Growth Effects of Fiscal Policies: An Application of Robust Modified M-Estimator. Applied Economics 41(7): 899-912.

Connolly M, Li C (2016) Government spending and economic growth in the OECD countries. Journal of Economic Policy Reform 19(4): 386-395.

Dar AA, Khalkhali SA (2002) Government Size, Factor Accumulation, and Economic Growth: Evidence from OECD Countries. Journal of Policy Modeling 24(7-8): 679_ 692.

Data Planet (2021) Data Planet Statistical Datasets by SAGE Publishing Resource

Dogan E, Turkekul B (2016) CO2 emissions, real output, energy consumption, trade, urbanization and financial development: testing the EKC hypothesis for the USA. Environmental Science and Pollution Research 23(2): 1203- 1213.

Dogan E, Ozturk I (2017) The influence of renewable and non-renewable energy consumption and real income on $\mathrm{CO} 2$ emissions in the USA: evidence from structural break tests. Environmental Science and Pollution Research 24(11): 10846-10854.

Eberhardt M, Teal F (2010) Productivity analysis in global manufacturing production. University of Oxford Department of Economics Discussion Paper Series 515.

EIA (2021) https://www.eia.gov/state/seds/seds-data-complete.php

Grossman G.M, Krueger AB (2019) Environmental Impacts of a North American Free Trade Agreement. National Bureau of Economic Research Working Paper: 3914, NBER, Cambridge MA. 
Isık C, Ongan S, Ozdemir D (2019) Testing the EKC hypothesis for ten US states: an application of heterogeneous panel estimation method. Environmental Science and Pollution Research 26(11):10846-10853.

Karras G (1997) On the Optimal Government Size in Europe: Theory and Empirical Evidence. The Manchester School 65(3): 280-294.

Khan I, Hou F (2021) Does multilateral environmental diplomacy improve environmental quality? The case of the United States. Environmental Science and Pollution Research (Forthcoming).

Knoop TA (1999) Growth, Welfare, and the Size of Government. Journal of Economic Inquiry 37(1): 103-119.

Lucas RE (1988) On the mechanics of economic development. Journal of Monetary Economics 22: 3-42.

Ongan S, Isik C, Ozdemir D (2021) Economic growth and environmental degradation: evidence from the US case environmental Kuznets curve hypothesis with application of decomposition. Journal of Environmental Economics and Policy 10(1): 14-21.

Pesaran MH (2004) General diagnostic tests for cross section dependence. CESifo Working Paper 1229.

Pesaran MH, Ullah A, Yamagata T (2008) A bias-adjusted LM test of error cross-section independence. The Econometrics Journal 11: 105-127.

Pesaran MH, Yamagata T (2008) Testing slope homogeneity in large panels. Journal of Econometrics 142(10): 50-93.

Pesaran MH (2007) A simple panel unit root test in the presence of cross-section dependence. Journal of Applied Econometrics 22: 265-312.

Rajput S, Tariq A (2019) Government Size and Economic Growth: A Panel Data Study Comparng OECD and Non-OECD Countries. Applied Economics Journal 26(2): 2237.

Romer PM (1986) Increasing returns and long-run growth. The Journal of Political Economy 94: 1002-1037. 
526 Roy AG (2009) Evidence on Economic Growth and Government Size. Applied Economics

$527 \quad 41: 607-614$.

528 Sarte PD (2001) Rent-seeking bureaucracies and oversight in a simple growth model.

$529 \quad$ Journal of Economic Dynamics and Control 25: 1345-1365.

530 Shahbaz M, Solarin SA, Hammoudeh S, Shahzad SJH (2017) Bounds testing approach to 531 analyzing the environment Kuznets curve hypothesis with structural beaks: the role 532 of biomass energy consumption in the United States. Energy Economics 68:548-565.

533 Solow RM (1956) A contribution to the theory of economic growth. The Quarterly Journal 534 of Economics 70: 65-94.

535 Scully GW (1994) What is the Optimal Size of Government in the US? Policy Report 188, $536 \quad$ National Center for Policy Analysis.

537 Urban, (2021) https://state-local-finance-data.taxpolicycenter.org/pages.cfm

538 Vedder RK, Gallaway LE (1998) Government size and economic growth. Paper prepared 539 for the Joint Economic Committee of the US Congress, Washington.

540 Westerlund J (2007) Testing for error correction in panel data. Oxford Bulletin of $541 \quad$ Economics and Statistics 69(6): 709-748.

542

543 